\title{
Whipple's disease: comparison of histology with diagnosis based on polymerase chain reaction in four consecutive cases
}

\author{
C Müller, D Petermann, C Stain, H Riemer, H Vogelsang, P Schnider, K Zeiler, F Wrba
}

\begin{abstract}
Background-Polymerase chain reaction (PCR) based detection of species specific sequences of the $16 \mathrm{~S}$ rRNA gene of Tropheryma whippelii is a recently described method for diagnosis of Whipple's disease.
\end{abstract}

Aims-Comparison of histology with PCR in mucosal samples of patients with Whipple's disease before, during, and after treatment. Detection of $T$ whippelii in peripheral blood mononuclear cells as a non-invasive test for infection.

Methods-Four consecutive patients with histologically proven Whipple's disease were studied prospectively.

Results-In untreated patients biopsy specimens taken from regions with PAS positive macrophages gave a positive result with PCR for T whippelii; however, a PCR signal was also found in tissue biopsy specimens from mucosal regions with negative histology. In two of the patients the PCR performed with nucleic acids extracted from peripheral blood mononuclear cells was positive. After treatment with sulfamethoxazole/trimethoprim the PCR became negative after one month in two patients and after two months in the third patient treated, whereas PAS positive macrophages were found throughout the treatment period in two patients and disappeared in only one of them thereafter.

Conclusions-Detection of $T$ whippelii specific sequences based on the PCR is useful to confirm the diagnosis, is able to detect a positive signal in samples taken from histologically negative mucosal areas, and can be used to monitor treatment. The PCR can sometimes be positive in peripheral blood mononuclear cells, but this cellular compartment cannot be taken as a substitute for duodenal biopsy specimens in the diagnosis of Whipple's disease.

(Gut 1997; 40: 425-427)

Keywords: Whipple's disease, intestinal lipodystrophy, PAS positive macrophages, Tropheryma whippelii, polymerase chain reaction diagnosis.

Whipple's disease is a multisystem bacterial infection associated with malabsorption, diar- rhoea, weight loss, fever, adenopathy and polyarthritis. ${ }^{12}$ Biopsy specimens from small bowel or lymph nodes disclose Gram positive bacteria in macrophages resistant to diastase treatment on periodic acid-Schiff staining. Both electron microscopy ${ }^{4}$ or the detection of species specific bacterial ribosomal RNA (rRNA) gene by polymerase chain reaction (PCR) ${ }^{5}$ can be used to confirm the diagnosis. Sequence analysis of the species specific gene of $16 \mathrm{~S}$ rRNA of Tropheryma whippelii allowed it to be grouped as a member of actinomycetes.

Although the diagnosis is usually made by the demonstration of PAS positive macrophages in the lamina propria of the jejunum or duodenum, extraintestinal manifestation of the disease can be present even in the absence of histologically established involvement of the duodenum. The PCR, as a much more sensitive method than histology, should allow a diagnosis of Whipple's disease to be made in PAS negative biopsy samples. We report four prospectively studied consecutive patients with histologically proven Whipple's disease in whom we systematically biopsied duodenal and gastric mucosa at different locations for both histology and PCR based diagnosis. In addition, we performed follow up biopsies in these patients at regular intervals before and after initiation of antibiotic treatment. As the presence of $T$ whippelii in blood cells has been described, ${ }^{78}$ we also analysed peripheral blood mononuclear cells by PCR.

\section{Methods}

\section{Patients}

Four patients with histologically established Whipple's disease were investigated. Table I gives the clinical details. Three of the patients had PAS positive macrophages in the duodenal mucosa, whereas in one patient (patient 2) PAS positive macrophages and granuloma formation suggesting Whipple's disease was found in a biopsy sample of a mesenteric lymph node. Endoscopic duodenal biopsy did not show PAS positive macrophages in this patient, but PCR for $T$ whippelii from this specimen was positive, confirming the diagnosis. Some of the clinical details and PCR findings of patient $1^{7}$ and patient $2^{9}$ have been reported previously. 
TABLE I Clinical details of patients with Whipple's disease

\begin{tabular}{|c|c|c|c|c|c|c|c|}
\hline Patient & Sex & Age (y) & Symptoms & Clinical findings & $P A S+$ macrophages in & Treatment & Outcome \\
\hline 1 & $\mathbf{M}$ & 58 & $\begin{array}{l}\text { Anorexia, malaise, recurrent } \\
\text { athritis, night sweats }\end{array}$ & $\begin{array}{l}\text { Lymphadenopathy, pleural } \\
\text { effusion }\end{array}$ & Duodenal mucosa & $\begin{array}{l}\text { Gentamycin+penicillin G } \\
\text { for } 2 \text { weeks (iv) SMX-TMP }\end{array}$ & Complete recovery \\
\hline 2 & $\mathbf{M}$ & 50 & $\begin{array}{l}\text { Recurrent fever, } \\
\text { neurological symptoms }\end{array}$ & $\begin{array}{l}\text { Cachexia, hyperpigmentation, } \\
\text { dyskinetic eye movements, } \\
\text { jerks }\end{array}$ & $\begin{array}{l}\text { Mesenteric lymph node, } \\
\text { (duodenal mucosa negative) }\end{array}$ & $\begin{array}{l}\text { Penicillin G+amikacin for } \\
10 \text { days (iv) ceftriaxone, } \\
\text { SMX-TMP }\end{array}$ & $\begin{array}{l}\text { Severe neurological } \\
\text { sequelae }\end{array}$ \\
\hline 3 & $\mathrm{~F}$ & 42 & $\begin{array}{l}\text { Fever, arthritic pain, } \\
\text { neurological symptoms }\end{array}$ & $\begin{array}{l}\text { Buccofacial dyskinesia, } \\
\text { ophthalmoplegia }\end{array}$ & Duodenal mucosa & SMX-TMP & $\begin{array}{l}\text { Slight neurological } \\
\text { improvement }\end{array}$ \\
\hline 4 & $\mathbf{M}$ & 65 & Weight loss, diarrhoea & Cachexia & Duodenal mucosa & SMX-TMP & Lost to follow up \\
\hline
\end{tabular}

SMX-TMP=sulfametoxazole $(800 \mathrm{mg}) /$ trimethoprim $(160 \mathrm{mg})$ twice daily for one year; $\mathrm{PAS}+=T$ whippelii specific DNA sequences of $16 \mathrm{~S}$ rRA gene detected in biopsy specimen.

\section{Methods}

Tissue samples - Four biopsy specimens were taken by grasp forceps during gastroscopy from each of the following sites: descending duodenum, superior duodenum, pyloric antrum, and body region of the stomach. Two biopsy specimens each were fixed in formalin, embedded, and stained with routine hematoxilin and eosin and periodic acid-Schiff stain. Two other specimens from the same locations were stored at $-80^{\circ} \mathrm{C}$ until further processing. Peripheral blood was drawn before endoscopy and peripheral blood mononuclear cells were harvested using density gradient centrifugation and stored at $-80^{\circ} \mathrm{C}$. Follow up biopsies from the inferior duodenum were performed one, two, four, and nine months after start of antibiotic treatment, at 12 months (after end of therapy), and at 15 months. Duodenal tissues from two control patients, examined with the same washed and desinfected gastroscope immediately after a patient with Whipple's disease, gave negative PCR results for $T$ whippelii. In 75 duodenal biopsy samples analysed for the presence of $T$ whippelii by PCR no false positive finding was found.

PCR analysis - PCR was performed according to the method described by Relman et $a l^{6}$ with some modifications. Two biopsy samples from the same location were always processed in parallel. Tissues or peripheral blood mononuclear cells was lysed in $4 \mathrm{M}$ guanidium isothiocyanate containing $1 \%$ mercaptoethanol, dialysed overnight, and extracted by the standard phenol/chloroform/ethanol method. For PCR amplification a nested PCR protocol was used with confirmation of the specific product of 211 bp length by hybridisation with an internal digoxigenin labelled oligonucleotide.

\section{Results}

Diagnostic results before treatment

In the descending and superior duodenum PCR was positive from biopsy material in all

TABLE II Histology and PCR results from duodenum and stomach, and PCR from peripheral blood mononuclear cells (PBMC) at the time of diagnosis before treatment

\begin{tabular}{|c|c|c|c|c|c|c|c|c|c|}
\hline \multirow[b]{2}{*}{ Patient } & \multicolumn{2}{|c|}{$\begin{array}{l}\text { Descending } \\
\text { duodenum }\end{array}$} & \multicolumn{2}{|l|}{$\begin{array}{l}\text { Superior } \\
\text { duodenum }\end{array}$} & \multicolumn{2}{|l|}{$\begin{array}{l}\text { Pyloric } \\
\text { antrum }\end{array}$} & \multicolumn{2}{|c|}{$\begin{array}{l}\text { Body region } \\
\text { of stomach }\end{array}$} & \multirow{2}{*}{$\begin{array}{l}P B M C \\
P C R\end{array}$} \\
\hline & Histology & $P C R$ & Histology & $P C R$ & Histology & $P C R$ & Histology & $P C R$ & \\
\hline 1 & + & + & + & + & - & + & - & - & + \\
\hline $2^{\star}$ & - & + & - & + & - & - & - & - & - \\
\hline 3 & + & + & + & + & + & + & - & - & - \\
\hline 4 & + & + & + & + & + & + & - & + & + \\
\hline
\end{tabular}

*Diagnosis was confirmed histologically by PAS positive lymph node. Histology+=PAS positive macrophages found in biopsy specimen; $\mathrm{PCR}+=T$ whippelii specific DNA sequences of $16 \mathrm{~S}$ rRNA gene detected in biopsy specimen. four patients, whereas PAS positive macrophages were found in three of those patients only. One patient (patient 2) had no PAS positive macrophages in the lamina propria; in this patient Whipple's disease was histologically verified by PAS positive macrophages in a mesenteric lymph node. In biopsy specimens taken from the pyloric antrum both histology and PCR results were positive in patients 3 and 4 , whereas patient 1 had a negative histology but a positive PCR. In patient 2 histology and PCR were negative. In the body region patient 4 still had a positive PCR but a negative histology; the other three patients were negative histologically and with PCR. The PCR for $T$ whippelii was positive in peripheral blood mononuclear cells from patients 1 and 4 , but negative in patients 2 and 3 (Table II).

\section{Follow up}

Three patients could be followed up for a year during antibiotic treatment. In patients 1 and 2 PCR from duodenal samples became negative after one month of therapy, in patient 3 after two months. Histology, however, continued to show PAS positive macrophages in two patients ( 1 and 3 ) over the treatment period. Patient 2, in whom PAS positive macrophages were found in a lymph node but not in the duodenal mucosa, was histologically negative throughout the study period. Three months after the end of treatment histology was positive in patient 1 , but PCR remained negative. Patient 2 continued to have negative histology and PCR results. Patient 3 was tested after the end of the treatment period at 12 months and was negative by both histology and PCR. Patient 1 was positive for $T$ whippelii in peripheral blood mononuclear cells by PCR at the time of diagnosis, but became negative after one month of antibiotic therapy. The other patient with $T$ whippelii in peripheral blood mononuclear cells was lost to follow up during treatment.

\section{Discussion}

The extremely sensitive PCR method promises detection of microorganisms in tissues at a density below the detection limit of conventional methods such as histology. This was found in our patients with Whipple's disease, with positive PCR results in biopsy samples from PAS negative regions. Specimens taken systematically from the descending duodenum towards the stomach disclosed a declining 
positivity rate for both histology and PCR; however, in three of four patients PCR gave a positive reaction at a location more proximal than the last PAS positive sample. We approached the question of contamination of samples with $T$ whippelii via the forceps used by taking consecutive biopsy specimens from the duodenum and the fundus region of the stomach in one patient; the first was PCR positive, the second PCR negative suggesting that carry over by the endoscopical forceps was not influencing the results. In one of the patients PAS loaded macrophages were found in a surgically removed mesenteric lymph node only, with duodenal mucosal samples being histologically negative; in this patient the duodenal tissue was positive by PCR. This finding shows the clinical usefulness of PCR for diagnosis of $T$ whippelii infection and confirms a similar finding by others. ${ }^{10}$ Extraintestinal manifestation of Whipple's disease without histologically demonstrable PAS positive macrophages in the intestinal mucosa is well known. ${ }^{11-14}$ The discrepancy between histology and PCR results could be explained either by a low number of bacteria in the intestinal mucosa, by a weak inflammatory response of the host not leading to a histologically discernible process, by a patchy pattern of the pathological lesions, ${ }^{15}$ or by a predominant involvement of the submucosa and not the lamina mucosa. ${ }^{16}$

In two of our four patients $T$ whippelii was found in peripheral blood mononuclear cells by PCR before treatment. One of these patients has been reported previously. ${ }^{7}$ The occurrence of $T$ whippelii in peripheral blood cells has also recently been shown in two splenectomised patients $^{8}$ using DNA extracted from whole blood and stored slides of peripheral blood. It is noteworthy, however, that only two of our patients with Whipple's disease had a positive PCR in peripheral blood mononuclear cells; this makes it clear that peripheral blood mononuclear cells cannot be taken as a substitute for mucosal biopsy specimens from small intestine in the diagnosis of Whipple's disease.

Follow up studies under therapy with sulfamethoxazole/trimethoprim disclosed that duodenal mucosa becomes negative by PCR within a short time period. In contrast to this rapid response PAS positivity in the mucosa persisted for at least nine months and was demonstrable in one patient three months after end of the one year therapy. Earlier reports using electron microscopy have also shown that the bacteria disappear soon after initiation of treatment, whereas PAS positive macrophages remain in the mucosa for a long time. ${ }^{17} 18$ In one reported patient using PCR the reaction was found to be negative after 15 months of therapy while PAS staining of mucosal biopsy specimens was still positive. ${ }^{19}$ The PCR might be a simpler and now more readily available technique for monitoring treatment effects than electron microscopy. However, it is unclear at present whether a negative PCR from mucosal samples of the small intestine should be used as a guide to end treatment.

Detection of $T$ whippelii based on PCR is useful to confirm the diagnosis, is able to detect infection with $T$ whippelii in histologically negative mucosal regions, and can be used to monitor therapy. The PCR is sometimes, but not always positive in peripheral blood mononuclear cells; testing this cellular compartment is therefore no substitute for the more invasive duodenal biopsy in diagnosing Whipple's disease.

1 Dobbins WO III. Whipple's disease. Springfield, IL: Charles C. Thomas, 1987.

2 Fleming JL, Wiesner RH, Shorter RG. Whipple's disease: clinical, biochemical, and histopathologic features and assessment of treatment in 29 patients. Mayo Clin Proc 1988; 63: 539-51.

3 Dobbins WO III, Kawanishi H. Bacillary characteristics in Whipple's disease: an electron microscopic study. Gastroenterology 1981; 80: 1468-75.

4 Silva MT, Macedo PM, Moura-Nunes JF. Ultrastructure of bacilli and the bacillary origin of the macrophagic inclusions in Whipple's disease. $f$ Gen Microbiol 1985; inclusions in

5 Wilson KH, Blitchington R, Frothingham R, Wilson JAP Phylogeny of the Whipple's-disease-associated bacterium Lancet 1991; 338: 474-5.

6 Relman DA, Schmidt TM, MacDermott RP, Falkow S Identification of the uncultured bacillus of Whipple's disease. $N$ Engl F Med 1992; 327: 293-301.

7 Müller C, Stain C, Burghuber O. Tropheryma whippelii in peripheral blood mononuclear cells and cells of pleural effusion. Lancet 1993; 341: 701.

8 Lowsky R, Archer GL Fyles G, Minden M, Curtis J, Messner $\mathrm{H}$, et al. Brief report: diagnosis of Whipple's disease by molecular analysis of peripheral blood. $N E n g$ f Med 1994; 331: 1343-6.

9 Schnider P, Trattnig S, Kollegger H, Auff E. MR of cerebra Whipple disease. AfNR Am $\mathcal{F}$ Neuroradiol 1995; 16: 1328-9.

10 Rickman LS, Freeman WR, Green WR, Feldman ST, Sullivan J, Russack V, Relman DA. Brief report: uveitis caused by Tropheryma whippelii (Whipple's bacillus). $N$ Engl f Med 1995; 332: 363-6.

11 Hollerbach S, Holstege A, Muscholl M, Mohr V, Rüschoff J, Geissler A, Schölmerich J. Maskierter Verlauf eine Morbus Whipple mit Uveitis, Sepsis, EndokardbeteiliMorbus Whipple mit Uveitis, Sepsis, Endokardbeteiliund Ubersicht. $Z$ Gastroenterol 1995; 33: 362-7.

12 Ereño C, Lopez JI, Elizalde JM, Ibañez T, Fdez-Larrinoa A Toldeo JD. A case of Whipple's disease presenting as supraclavicular lymphadenopathy. APMIS 1993; 101: 865-8.

13 Mansbach CM II, Shelburne JD, Stevens RD, Dobbins WO Lymph-node bacilliform bodies resembling those of Wymph-node bacilliform bodies resembling those of Whipple's disease in a patients without in

14 Feurle GE, Volk B, Waldherr R. Cerebral Whipple's disease with negative jejunal histology. N Engl f Med 1979; 300 907-8.

15 Moorthy S, Nolley G, Hermos JA. Whipple's disease with minimal intestinal involvement. Gut 1977; 18: 152-5.

16 Kuhajda FP, Belitsos NJ, Keren DF, Hutchins GM. A submucosal variant of Whipple's disease. Gastroenterolog 1982; 82: 46-50.

17 Feldman M. Southern Internal Medicine Conference: Whipple's disease. Am f Med Sci 1986; 291: 56-67.

18 Ectors N, Geboes K, De Vos R, Heidbuchel H, Rutgeerts P, Desmet V, Vantrappen G. Whipple's disease: a histological, immunocytochemical and electron microscopic study of the immune response in the small intestinal mucosa. Histopathology 1992; 21: 1-12.

19 Von Herbay A, Ditton HJ, Maiwald M, Meier-Willersen HJ. Nachweis von Tropheryma whippelii mit der PolymeraseKettenreaktion vor und nach Therapie eines $M$ Whipple. Dtsch Med Wochenschr 1994; 48: 1679. 